\title{
HISTORICO-DIDACTIC VECTOR \\ OF THE FORMATION AND DEVELOPMENT \\ OF METHODOLOGICAL COMPETENCE IN UKRAINE
}

\section{Rubinska B. I.}

\section{INTRODUCTION}

Research of philologists' specialized professional training needs to take into account its originality of school system and pedagogical science, methods of training philologists' development and their personal development, because content of their teaching is in close connection with methodological settings, worldview ideas, principles, norms of philological scientific cognition, student's development as a personality. Many historical changes have taken place on the territory of our country. Great changes that take place in Ukraine influence the problems solution of modern researchers. There are a lot of publications devoted to the problem of the notion "competence", "competency", "methodological competence". The way of their formation is analyzed in thesis by M. Bolina, M. Vachevsky, L. Demchuk, Yu. Yemelyanov, V. Kashnitsky, S. Kozak, I. Megalova, V.Ohotnikova, O. Pahomova, O. Petrova, O. Prozorova, O. Semenog, A. Trofimenko, O. Usyk and many others. In order to define the topicality of the formation of methodological competence of a student-philologist, finding ways of its formation, we think it is necessary to analyze the content of professional training and those traditions and tendencies that formed in the historical development of philological sciences and modern education in Ukraine.

It is recognized by scientists that "a discipline" is a structural organizational didactic unit. It has its own subject and methods of investigation, a set of facts, uses the scientific language, hypothesis, laws, theories etc. Philological disciplines are united into one group on the basis of studying one object - the language. They have common and similar methods of investigation; are based on the laws of General Linguistics. We have already written about different approaches to the 
definition "Philologist"1 and will base our understanding of the term on the following: "English philologist is a specialist, who not only has mastered a foreign language, grammar and stylistics in use, but also knows its culture, oral communication and literature. For the English philologist it is important to have good pronunciation, know the language perfectly. Such specialist spends a lot of time on translation, that's why good memory, ability to concentrate and correctly plan one's time are very important",2.

In order to understand modern state of the content of forming Philological competence formation development in Ukraine it is necessary to consider the notion "Philology" from the historical point of view. The aim of our article is to consider it through the activity of outstanding historical and scientific personalities and trace elements of methodological competence formation in the development of pedagogical and philological views of the periods in history.

\section{The problem's prerequisites emergence and the problem's formulation}

As noted above, the problem of personal formation of students philologists in the aspect of their professional development must be constantly in the center of attention of higher school. In order to achieve this the system of educational process must be built on the basis of student's development as a personality and as a professional. In the context of specificity of student's age as an important stage of personality development this problem was considered by B. Ananyev, A. Bodalev, D. Dvoryashyn, N. Peysahov, O. Stepanova and others. The definition of the role and place of abilities, interests, motives and personality traits in the formation of professionally important qualities were given by Ye. Zeyer, T. Kudryavtseva, B. Lomov. The question of student's individual development, the formation of his readiness to future professional activities are the key ones in the theory and practice of improvement of modern educational establishment work. One of the leading problems is the formation of such educational process system that will optimally take into account not only peculiarities and patterns of

\footnotetext{
${ }^{1}$ Рубінська Б. Про підходи до відбору компетенцій філолога. Міжнародний філологічний часопис. 2020. Вип. № 11 (3). С. 137-142. DOI: 10.31548/philolog2020.03.023.

2 Професія - філолог. URL: https://kudapostupat.ua/profesia-filoloh (дата звернення: 02.04.2021).
} 
personal development but professional development as a specialist as well ${ }^{3}$. According to research of G. Raven "methodological competence includes tendencies to more exact understanding of values and settings as to the concrete aim; tendencies to control your own aims; involvement of emotions in the process of activity; readiness and ability to study independently; search and use of feedback; self-confidence; self-control; adaptability; propensity to think about the future; attention to the problems connected with achievement of the set goals; independence of thinking; originality; critical thinking, willingness to solve complex issues; willingness to work on something controversial and anxious; readiness to rely on subjective assessments and go at moderate risk; readiness to use new ideas and innovations to achieve the goal; the focus on mutual win and the breadth of perspective: trust; attitude to the rules as indicators of desirable behaviors; the ability to make the right decisions; personal responsibility; ability to work together to achieve the goal; the ability to induce others to achieve the goal; the ability to listen to other people and take into account what they said; the desire to subjectively evaluate the potential of employees; readiness to allow other people to make independent decisions; the ability to resolve conflicts and mitigate differences; the ability to work successfully as a subordinate; tolerance for the different lifestyles of others; understanding pluralistic policy as well as readiness to carry out organizational and social planning". 4

In order to understand modern way of the development of Philology, which is a constituent part of students' knowledge, it is necessary to look at its development from the historical-didactic point of view.

There are different classifications of the history of Philology and Pedagogics, mostly connected with its development on the territory of tsarist Russia, whose part Ukraine was (A. Hrolenko, K. Nagayeva, N. Doronina and others). Historic-didactic analysis of the formation and development of Philology in Ukraine is necessary to perform on a certain principle. We have chosen the principle of considering the period in history from the personality activities point of view because we believe that history of Philology and Pedagogics is created by personalities and

3 Жеребкина И. Введение в гендерные исследования : учебное пособие. Харьков, 2001. С. 51.

4 Малихін О., Рубінська Б. Про потенціал формування методологічної компетентності в галузі підготовки кваліфікованих спеціалістів в галузі філологічних спеціальностей. Педагогічні науки. Херсон, 2018. Вип. LXXXII. C. $176-181$. 
worked out our own classification. The $\mathrm{I}^{\text {st }}$ period is connected with the name of Pamvo Berynda, Yu. Rusin, I. Galyatovsky, S. Polynetsky. The II $^{\text {nd }}$ period may be recognized through the name of Friderich August Wolf, G. Scovoroda. The III ${ }^{\mathrm{d}}$ period is related to the XIX century. It is associated with the names of such outstanding personalities as $\mathrm{V}$. Vernadsky and O. Potebnya. We connect the IV ${ }^{\text {th }}$ period with the end of the XIX ${ }^{\text {th }}$ and the beginning of the $X^{\text {th }}$ century and activities of M. Grushevsky. The $\mathrm{V}^{\text {th }}$ and the $\mathrm{VI}^{\text {th }}$ period $\left(1920-1930^{\mathrm{s}}\right)$ is the continuation of M. Grushevsky's activities. The $\mathrm{VI}^{\text {th }}$ period (1920$1930^{\mathrm{S}}$ ) brings into historical arena outstanding teachers such as A. Makarenko. The VII ${ }^{\text {th }}$ can be connected with the revival of foreign language teaching and M. Grushevsky. The VIII ${ }^{\text {th }}$ period began in the $50^{\mathrm{s}}$ and is closely connected with such outstanding Ukrainian philologists as L. Bulahovsky, M. Grushevsky, P. Zhytetsky. The IX ${ }^{\text {th }}$ period, is the period of "Khrushchev's warming". M. Zhovtobryukh can be called one of the most important specialists in studying the language of journalists. The $X^{\text {th }}$ period began at the beginning of the XXI century. Ukraine has entered the Bolonnia process and adopted a lot of important laws on education, which resulted in the change of the system of education in general and the system of higher education, in particular. There are so many outstanding figures in Linguistics and they are so difficult to choose. This period is associated with my teachers: the outstanding phonetician M. Dvorzhetska, the founder of the school of Phonetics, I. Korunets, whose books are used to teach translators all over Ukraine.

The $\mathrm{XI}^{\text {th }}$ period started with the beginning of COVID-19.

\section{Pre-history of the question}

The roots of the question can be traced in ancient history times. The question of adaptability to nature was one of the main in prehistoric times in the "pedagogical ideas" of ancient tribes. In Ancient Greece and Rome the philosophers and writers were interested in the questions of education and one of the modern disciplines-Rhetorics. The representatives of sophistics Korak and Tisiy thought that any man has the right to his point of view, which is one of components of modern ideas on methodological competence - independence of thinking; originality; critical thinking, willingness to solve complex issues. The basic notions of Phonetics and Grammar were formulated by Faximax, who paid much attention to the sounds of oral speech and was the first to introduce such notion as "period". 
We can also find interest in the choice of content of teaching in the works by Socratis, Platon, Aristotel and Democretus. Platon distinguished the questions of belief and education. He was one of the promoters of the necessity to choose oral ways of teaching. His former pupil Aristotel continued the development of his ideas in Logics, which most of modern scientists use. His main pedagogical ideas were that Didactics is not as important as stimulation of original thinking that further on brings satisfaction from learning. This is also one of the components of the modern system of methodological competence formation. He was also the founder of modern stylistic figures such as metaphor, comparison and others. The ideas of the Greek outstanding writers and educators began to degrade in the Roman empire. Learning by heart of the speeches of famous orators became the main method of teaching and so the content of education changed. Kwintilian was the first to pay attention to the personality of each pupil, his education and morality, studies of Philosophy and sophistication of speech. Thus new eloquence in the style of speaking began.

According to B. Grekov, writing was used in pagan schools in the IX $^{\text {th }}$ century in the Old Russ schools ${ }^{5}$. Dialectics, Rhethorics, Grammar and Arithmetics were taught in them. Encyclopedia knowledge was chosen for the content of teaching. Monks - chroniclers were the first translators of articles from "Izbornik", the first collection of articles on history, philosophy, poetics and others. Teaching writing, reading, counting and choir singing were the subjects taught and the main content of teaching was characterized as purely religious. In the XII ${ }^{\text {th }}$ century the idea of respectful attitude to studying foreign languages was expressed by Volodymir Monomah. Monk G. Armatol compiled his "Chronicles" on the basis of Greek mythology. Since then Greek culture became an integral part of Old Russ culture, in particular, in prose, Poetics, decorative art.

\section{The Classification of periods and their description}

We have based our understanding of the term on different sources. According to Levkivsky the first national renaissance began in the XVI century ${ }^{6}$ The first period is connected with the name of Pamvo Berynda, a famous lexicographer, poet, translator and editor, who had

\footnotetext{
${ }^{5}$ Греков Б. Киевская Русь. Москва, 1953. 567 с.

6 Левківський М. Історія педагогіки : навчально-методичний посібник. Київ, 2011. $190 \mathrm{c}$.
} 
great influence on the development of the Russian, Byelorussian and Ukrainian nations, from whose activities Philology started to develop ${ }^{7}$. Pamvo Berynda was a highly educated person. He knew lots of languages among which German, Volyn, Greek, Dalmatian, Old Jewish, Latin, Moscow, Polish, Russian, (i.e. Old Ukrainian,or West Russian, or Old Byelorussian, or Kyev Russ times language), Syrian, Slovakian, Chech and Slavic. Fraternal schools began to be established in towns and villages in Ukraine in the $80^{\mathrm{s}}$ of the $\mathrm{XVI}^{\text {th }}$ century that played an important role in the choice of content of teaching. They differed from church and parish schools in many ways, especially in the choice of content of teaching. Pamvo Berynda worked in one of them. KyivMohyla collegium in Kyiv became the center of education in Ukraine. The studies lasted for 12 years. Subjects were divided into the so-called ordinary and non-ordinary. Fara, Infima, Grammar, Syntax, Poetics, Rhetoric, Philosophy and Theology belonged to ordinary ones. Greek, Polish, German, French, Jewish and Russian were taught in non-ordinary classes. Russian language and poetry began to be taught in 1751 . In 1784 it was prohibited to deliver lectures in Ukrainian ${ }^{8}$. In 1817 it was closed. Its traditions could be traced in Kyiv snt Volodymir University. Ostrog three languages collegium, founded by K. Ostrozsky and Lviv University, which originated from jesuit colegium were the two higher educational establishments in Ukraine. Among outstanding Ukrainian professors we can name Yu. Rusin, who in 1691 took part in publishing the first books in Slavic language, among which was Horology for teaching children to read and write. He was a professor in Krakiv and a poet, who was influenced by the Renaissance ideas. His creative activity made great influence on Ukrainian spiritual life. "The Grammar of Ukrainian Language" is one of the most influential philological works. It was published in 1619 by M. Smotritsky and was used all over the territory of Russia until 1755. M. Lomonosov highly appreciated it and called "the gate of knowledge". He worked out orthography, orienting on the Old Slavic language as a protolanguage on which all other Slavic languages were based. In Pedagogics we can't but mention another specialist - I. Galyatovsky, who wrote "Science or ways of composing stories", a booklet on Rhetorics. Ye Slavinetsky, who oriented his

${ }^{7}$ Хроленко А. История филологии : учебное пособие. Москва, 2013. 136 с.

${ }^{8}$ Хижняк 3., Маньківський В. Історія Києво-Могилянської академії. Київ, 2003. C. 74-76. URL: http://irbisnbuv.gov.ua/ulib/item/UKR0000716 (дата звернення: 27.03.2021). 
pedagogical system on the examples of Greeks and S. Polynetsky, who based his theoretical ideas on the Slavic pedagogical traditions and west European Pedagogics, were also outstanding educators of that period.

The II ${ }^{\text {nd }}$ period, called "the stage of new Philology", which began at the end of the XVIII-XIX ${ }^{\text {th }}$ centuries may be recognized through the name of Friderich August Wolf. We have chosen this personality because he was the first student in Gettingham, Germany, who wrote himself as Studiosus Philologiae, it means that he used it to name his profession. ${ }^{9}$ This is the time when Philology starts. When he began working, he slightly changed his understanding of Philology. He understood it as "the main content of knowledge and news that gets us acquainted with actions and fates, political, scientific and home state of the Greeks and Romans, their culture, language, art and science, moral standards, religion, national character and way of thinking in such a way that we have an opportunity to understand their creations profoundly and enjoy them, plunging deeply into their content and spirit, creating antique life and comparing it with the following and modern". He preserved the understanding of Philology as historical-philological complex of knowledge about ancient nations. The problem of understanding becomes the primary one. It can be studied with the help of different scientific methods, which are used in studying any language. It was the epoch of Peter I and the development of different sciences. M. Lomonosov and his activities influenced the future of education and its content a lot. G. Scovoroda is a famous Ukrainian, who taught Poetics, Syntax, the Greek language and "the Course of Benevolence" in his own way ${ }^{10}$ with the help of his own textbook in Kharkiv collegium, which was not approved of and he was fired. The most important creations of his are: "The Garden of God's Songs", "Kharkiv Fables", treatises, dialogues and fables, where he expressed his ideas. The III ${ }^{\mathrm{d}}$ period is related to the XIX ${ }^{\text {th }}$ century. Philology is divided into national (Germanic, Romance, Slavic, which includes Ukrainian, Turkish etc.) and a complex of knowledge, which includes such sciences as

\footnotetext{
${ }^{9}$ Нагаева К. История филологического знания. Москва, 2020. С. 6-7. URL: https://ru.calameo.com/read/005704444599fd494d854 (дата звернення: 04.04.2021).

10 Сковорода Григорій Савич. Вікіпедія : вільна енциклопедія. URL: https://uk.wikipedia.org〉wiki> Сковорода_Григорій (дата звернення: 04.04.2021) ; Хижняк 3., Маньківський В. Історія Києво-Могилянської академії. Київ, 2003. C. 74-76. URL: http://irbisnbuv.gov.ua/ulib/item/UKR0000716 (дата звернення: 27.03.2021).
} 
Introduction into Linguistics, Literature studies, Folklore. Historical Introduction into Linguistics, General Linguistics, History of Literature, Literary Criticism appear and new schools of Philology emerge. They are associated with the names of such outstanding personalities as Ch. Bally, F.de Saussur, V. Vinogradov, S. Ozhegov, V. Vernadsky and O. Potebnya in Ukraine. O. Potebnya is the representative of Kharkiv school, the founder of the school of Philology in Ukraine. He studied the origin and development of languages in a wide cultural and historic context. According to the research by N. Doronina there existed different universities in Ukraine such as those in Kharkiv, Kyiv and other. The snt Volodymir University was founded in Kyiv in $1834^{11}$. The development of science in these universities was in close coordination with the tendencies of european school ${ }^{12}$. Ministry of Education of the Russian empire influenced this process as it understood the necessity of scientific centers that could spread not only science and education but be the means of russification of this area. Another reason of it was that it could oppose polonization of Ukrainian lands. St Volodymyr and Kharkiv universities were firstly a copy of German university system. Yet many special features of gymnasium were created by its professors. The structure of University in Kyiv included two faculties: Philosophy and Law. The first department included the chairs of Philosophy, Departments of Greek literature and antiquities, Russian Literature, Statistics, General and Russian History. The second department included different sciences. Philology was developing in them. Lecturers on Westeuropean languages were delivered by the staff. According to Wikipedia there existed a longer than in the west humanistic unity of Philology and its connection with the History in Ukraine. The same personalities worked in different sectors of History and Philology. This period is connected with such names as O. Potebnya, O. Ohonovsky, P. Zhytetsky, V. Perets, M. Grushevsky. O Potebnya is an outstanding linguist, the founder of the so-called Psychological direction in Slavic linguistics. His works on Phonetics, stress, Grammar, Semantics and Etimology, Dialectology, theory of Literature, Folklore, Ethnography, research on the origin of the language and thinking are well-known in

11 Дороніна Н. До історії розвитку іноземної філології в Київському університеті у XIX-XX ст. Етнічна історія народів Свропи. Київ, 2011. Вип. 35. С. 86.

12 Дороніна Н. До історії розвитку іноземної філології в Київському університеті у XIX-XX ст. Етнічна історія народів Свропи. Київ, 2011. Вип. 35. С. 86-89. 
linguistic circles. He considered language in the context of culture. He positioned the language in one more essential relationship - to nation and nationality. Language is the expression of "nation's spirit", it defines national independence of community, coding in the structures created by it of an "intermediate world", special national outlook. He strongly protested against denationalization and deukrainization, in particular, as spiritual decay because as a result it threatened the disappearance of the language and led to the loss of ethnic uniqueness. "In addition, the disappearance of at least one language (and each language is a complete, "deeply different system of thinking techniques") would lead to the loss of universal culture of a whole group of thought processes associated with it, and as a result of replacing "differences of languages with one universal" humanity would experience a "decrease in the level of thought". Because universal culture, according to Potebnya, is an integrative product of different national cultures, it exists through their interaction. Intercultural dialogue creates opportunities for the assimilation of other nations cultural elements, for self-development and, consequently, for the progress of world culture" Kharkiv historical and philological society was his creation ${ }^{13}$. Important changes have taken place in the development of training higher education system for women. According to Latyshina ${ }^{14}$ at the first stage Moscow higher women's courses were opened and then in 1878 by analogy in Kazan, Snt Petersburg and Kyiv. At the second stage they were reopened in Snt Petersburg and Moscow. At the third stage the number of communal and private courses grew. They appeared in different cities and towns of Russia and Ukraine, in Kyiv (1878), Odessa, Kharkiv. The greatest number of students were at the History and Philology department and Physics and mathematics department. Since 1900 two faculties began to work at Moscow higher women's courses: History and Philology department and Physics and Mathematics department. As Pedagogics and Methods were not taught, courses listeners, trying to get rid of lacunes in their training, began to create pedagogical circles. Later they were turned into Pedagogical Society, which spread literature, organized disputes, meetings, conferences. Trial lessons at school were given. One of the main pedagogical disciplines in the curriculum was "The basics of

13 Потебня Александр Афанасьевич. Biкineдія : вільна енциклопедія. URL: https://ru.wikipedia.org〉wiki (дата звернення: 03.04.2021).

14 Латышина Д.И. История образования и педагогической мысли. Разд. I. URL: https://studentam.net/content/view/1536/125/ (дата звернення: 04.04.2021). 
education and beginning methods of teaching". Specialization began at the beginning of the $\mathrm{XX}^{\text {th }}$ century. History-Philological Institutes in St. Petersburg and Nezhyn (since 1867) had to train teachers for gymnasiums. Their main direction in the contents of teaching was classical languages and literature. History of Pedagogics, General Pedagogics and Didactics were studied as disciplines in Pedagogics. The content of education and the formation of methodological competence was connected with professional training of future teachers.

We connect the $\mathrm{IV}^{\text {th }}$ period with the end of the $\mathrm{XIX}^{\text {th }}$ and the beginning of the $\mathrm{XX}^{\text {th }}$ century and activities of M. Grushevsky. Besides the Romance and Germanic department was opened in snt Volodymir University in Kyiv thanks to activities of $\mathrm{M}$. Dashkevich and I. Sharovolsky. ${ }^{15}$ The content of professional training of future foreign language specialists was enriched. The peak of Grushevsky's activities is associated with the Ukrainian Revolution of 1917-1921. On the $3^{\mathrm{d}}$ of March he became the head of Ukrainian Central Rada, the main inspirer of Ukrainian national movement. He was the main political leader at that time. Besides political activities he worked out the conception of the Academy of Science as an association of scientists. During emigration Grushevsky began working at the 6 volume scientific project - the History of Ukrainian science. One of the main reasons he came back to Ukraine in 1924 was named by him. He said his aim was to finish the work of his life - "The History of Ukraine-Russ"16; 17.

The $\mathrm{V}^{\text {th }}$ period is characterized by the change in the focus of studying Western- European languages as they helped in studying specialized disciplines. Their content of teaching was chosen. This period has become the top in state activities of M. Grushevsky. He has founded the conception of the Ukrainian Academy of Science as the association of scientists. His scientific and editor's activities concentrated on the Ukrainian Institute of Sociology, which he organized. When he was in

15 Дороніна Н. До історії розвитку іноземної філологї в Київському університеті у XIX-XX ст. Етнічна історія народів Європи. Київ, 2011. Вип. 35. С. 86-89.

16 Шурхало Д. Михайло Грушевський після Центральної Ради: від боротьби за владу до «індивідуального подвигу». 2019. URL: https://www.radiosvoboda.org/a/29799890.html (дата звернення: 03.04.2021).

17 Грушевський Михайло Сергійович. Вікіпедія : вільна енциклопедія. URL: https://uk.wikipedia.org>wiki> Грушевський_Михайло (дата звернення: 03.04.2021). 
emigration he began working on multivolume "History of the Ukrainian Literature" in 6 volumes.

The VI ${ }^{\text {th }}$ period $\left(1920-1930^{\mathrm{s}}\right)$ can be viewed as the constant decrease in the spectrum and volume of studying foreign languages. Only German was taught in the former snt Volodymir University, which was reorganized into the Institute of Social Education. ${ }^{18}$ During this period M. Grushevsky was elected the Academician of the Academy of Science of the USSR. However, the pogrom of historical institutions created by Mykhailo Serhiiovych soon began: in 1930 the commission of the Historical Section, the Research Department of the History of Ukraine was liquidated, and all publications were closed. It is necessary to mention that great changes have taken place in the Soviet period in education. Special attention was paid to the teaching of Humanities, which task was the formation of communist worldview. personal responsibility; ability to work together to achieve the goal; the ability to induce others to achieve the goal are the elements of methodological competence chosen for Pedagogics. Verbal learning, which was criticized by the progressive educators before 1917, was revived at schools. Universities were liquidated and instead of them institutes of different profiles were providing higher education (industrial-technical, agricultural, socio-economic, pedagogical, medical and arts). As to Philology, great attention was paid to the creation and development of tests in the Ukrainian language spelling. (Kostuk, O. Rayevsky). Pedological service at school kept records of school performance, using tests and studied interests and ideals of children, defined their physical and intellectual development, but later it disappeared as a science. From the beginning of $30^{\mathrm{s}}$ national school began to loose its positions as school programs and textbooks of all republics of the USSR were unified. More time was alloted to the studying of the Russian language and teaching was in Russian ${ }^{19}$. During this period A. Makarenko organized his work colony for homeless and juvenile delinquents and wrote his famous

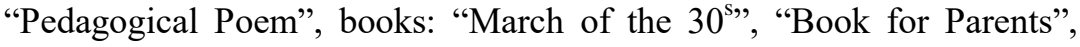
"Flags on the Towers". He connected the development of individuality not only with abilities of a person but temperament, features of character

18 Дороніна Н. До історії розвитку іноземної філології в Київському університеті у XIX-XX ст. Етнічна історія народів Європи. 2011. Вип. 35. C. $86-89$.

19 Латышина Д. История образования и педагогической мысли. Разд. 1. URL: https://studentam.net/content/view/1536/125/ (дата звернення: 03.04.2021). 
as well. He stated that the aim of individual upbringing is to define the perspectives of human development, the formation of character ${ }^{20}$. So he introduced into the system such component of methodological competence as personal responsibility; ability to work together to achieve the goal; the ability to induce others to achieve the goal the ability to listen to other people and take into account what they said.

The VII ${ }^{\text {th }}$ period can be connected with the revival of foreign language teaching. For example, the place of it in curricula was defined according to the needs of a faculty in the university: French at the Mathematics department, French and German at the literature and Linguistics department. In 1933 the training of specialists in teaching foreign languages at higher school began at the snt Volodymir University. ${ }^{21}$ A. Makarenko is also the symbol of outstanding teacher and linguist of this period.

The VIII ${ }^{\text {th }}$ period began in the $50^{\mathrm{s}}$ and is closely connected with such outstanding Ukrainian philologists as L. Bulahovsky, M. Grushevsky, P. Zhytetsky. Among the works on general linguistics by L. Bulahovsky are the book "Introduction to Linguistics" (Part 2, Moscow, 1953; $2^{\text {nd }}$ ed. - Moscow, 1954) and "Essays on General Linguistics" (K., 1955). Leonid Arseniyovych Bulakhovsky was the first to consider the issues of semasiology, lexicology, lexicography, and etymology (translated into Georgian, Polish, Bulgarian, and Chinese). In the second, he significantly expanded the issues covered and, along with these, outlined the issues of phonetics and phonology. The results of his research works has greatly influenced the theoretical linguistic disciplines and the choice of their content of teaching in philological departments.

The $\mathrm{IX}^{\text {th }}$ period, the period of "Khrushchev's warming". The importance of studying foreign languages as means of communication has been understood. In 1962 the Taras Shevchenko University was revived as a faculty of foreign languages, later (1970) renamed the Faculty of Romance and Germanic Philology, which existed until 2001. M. Zhovtobryukh can be called one of the most important specialists in studying the language of journalists. Among the printed works on the

${ }^{20}$ Ярмаченко М. Макаренко Антон Семенович. Еницилопедія освіти / гол. ред. В. Кремень. Київ, 2008. С. 471-472.

21 Дороніна Н. До історії розвитку іноземної філології в Київському університеті у XIX-XX ст. Етнічна історія народів Свропи. 2011. Вип. 35. C. 86-89. 
history of the Ukrainian literary language a special place is occupied by the book "Language of the Ukrainian Press (until the mid-nineties of the XIX century)" (1963), which was the first book of this kind. Teaching of Oriental languages as the specialty began in 1990 at the chair of oriental Philology at the department of Foreign Philology in the Kyiv National University named after T.G. Shevchenko. In 1995 Department of Oriental Philology as a faculty (Head of the Department, at the same time Head of the Department of Turkology - Prof. Hryhoriy Khalymonenko) was created ${ }^{22}$.The content of teaching oriental languages was revised and enriched by the ideas of communicative language teaching.

This period is connected with the work of outstanding teacher and educator V. Suhomlinskiy, who in 1947 came back to Pavlyshska secondary school in his native place. He published such monographies and books as "Education of Collectivism in Schoolchildren", "Secondary School Teachers" collective", "Education of Patriotism in School Children", "Education of Communist Attitude to Work", "The Spiritual World of a School Child", "Work and Moral Education", "How We Brought Up Courageous Generation", "Education of Personality in the Soviet School", "Pavlyshska Secondary school". His trilogy "I give my heart to children", "The Birth of a Citizen", "Letters to the Son" were devoted to the problems of personality formation, that meant enrichment of the content of education and such component of methodological competence as attitude to the rules as indicators of desirable behaviors; readiness and ability to study independently; search and use of feedback; self-confidence, the ability to listen to other people and take into account what they said, ability to create. His last two books were "Motherland in the Heart" and "Father's Pedagogics". He was the first to organize a fairy-tale room for the youngest schoolchildren where they were stimulated to create fairy-tales of their own. 70 volumes of them are preserved in memorial museum named after V. Suhomlinskiy. He taught children to read and write by using imaginary comparison with nature. His ideas were innovatory. It is not a well-known fact that when the teachers of literacy and primary school leaders refused to write creative

\footnotetext{
Сухомлинський B.O. Вiкineдія : вільна енциклопедія. URL: https://uk.wikipedia.org/Інститут філології Київського національного університету імені Тараса Шевченка (дата звернення: 03.04.2021).
} 
works, he himself presented 20 of his own (as it seemed to him best works )works at the sitting of seminar in Psychology ${ }^{23 ; 24}$.

The $\mathrm{X}^{\text {th }}$ period began at the beginning of the XXI century. Ukraine has entered the Bolonnia process and adopted a lot of important laws on education, which resulted in the change of the system of education in general and the system of higher education, in particular. There are so many outstanding figures in Linguistics and they are so difficult to choose. I will name my teachers: the outstanding phonetician M. Dvorzhetska, the founder of the school of Phonetics in KNLU, I. Korunets, whose books are used to teach translators all over Ukraine. This period is characterized by the great focus on teaching oriental languages and integration. New informational technologies in education and the necessity to train specialists that will be able to use different competencies created the need of modernization of higher education. It needed to renovate the content of education in higher school. Scientists had to research the problem on the basis of competence-oriented paradigme of the organization of educational activities in higher school as the leading one and through the prizm of hierarchal formation of higher educational establishments student. They worked out the conceptual basis of it(developed in the works of such scientists as V. Baidenko, N. Bibik, E. Bondarevskaya, A. Verbytsky, V. Guzeev, I. Zymnaya, M. Clarin, V. Kraevsky, A. Markova, L. Petrovskaya, O. Pometun, J. Raven, O. Savchenko, V. Serikov, S. Sysoeva, V. Slastyonin, L. Sokhan, E. Toffler, P. Khudominsky, A. Khutorsky, O. Tsokur, I. Yakimanskaya. Scientists, but still hadn't fully determined the essence, content and structure of educational activity of students of philological specialties taking into account the tasks of forming an active position of students of philological specialties in the research sphere in the process of joint educational activity.

The $\mathrm{XI}^{\text {th }}$ period started with the beginning of COVID-19. The education process needed new knowledge of work with different educational platforms and new methods of teaching. A lot of research in Philology is now being done on new coinage of words connected with COVID-19 in texts and colloquial speech.

\footnotetext{
${ }^{23}$ Видатні українські мовознавці. URL: myronivka-osvita.gov.ua`news.

24 Левківський М. Історія педагогіки : навчально-методичний посібник. 4-е вид. Київ, 2011. 190 с.
} 


\section{CONCLUSIONS}

We have analyzed traditions and tendencies that formed in the historical development of philological sciences and education in Ukraine. We surveyed different sources and couldn't find unanimity in the classification of periods, so we created our own classification. The first period is connected with the name of Pamvo Berynda, Yu. Rusin, I. Galyatovsky, S. Polynetsky. The second period may be recognized through the name of Friderich August Wolf, G. Scovoroda. The third period is related to the XIX century. It is associated with the names of such outstanding personalities as V. Vernadsky and O. Potebnya. We connect the fourth period with the end of the XIX ${ }^{\text {th }}$ and the beginning of the $\mathrm{XX}^{\text {th }}$ century and activities of M. Grushevsky. The fifth and the sixth period $\left(1920-1930^{\mathrm{S}}\right)$ is the continuation of M. Grushevsky's activities. The sixth period $\left(1920-1930^{\mathrm{s}}\right)$ brings into historical arena outstanding teachers such as A. Makarenko. The seventh can be connected with the revival of foreign language teaching and $\mathrm{M}$. Grushevsky. The eightth period began in the $50^{\mathrm{s}}$ and is closely connected with such outstanding Ukrainian philologists as L. Bulahovsky, M. Grushevsky, P. Zhytetsky. The ninth period, the period of "Khrushchev's warming". M. Zhovtobryukh can be called one of the most important specialists in studying the language of journalists. The tenth period began at the beginning of the $\mathrm{XXI}^{\text {st }}$ century. Ukraine has entered the Bologna process and adopted a lot of important laws on education, which resulted in the change of the system of education in general and the system of higher education, in particular. This period is associated with my teachers: the outstanding phonetician M. Dvorzhetska, the founder of the school of Phonetics, I. Korunets, whose books are used to teach translators all over Ukraine. The eleventh period started with the beginning of COVID-19. By the beginning of the declaration of independence in Ukraine the system of training philologists has been formed. The system included different models, directions and stages of training. Scientific schools in methods of teaching and training philologists have been formed, the content of teaching was improving. The situation with COVID-19 has created the need in new methods of training philologists and professors have to equip themselves with the new content of work on new platforms. Each period is described from the point of view of the choice of content of teaching and the formation of the elements of methodological competence. 


\section{SUMMARY}

In order to define the topicality of the formation of methodological competence of a student-philologist, finding ways of its formation, we think it is necessary to analyze the content of professional training and those traditions and tendencies that formed in the historical development of philological sciences and modern education in Ukraine. The problem of personal formation of students - philologists in the aspect of their professional development must be constantly in the center of attention of higher school. In order to achieve this the system of educational process must be built on the basis of student's development as a personality and as a professional. In the center of this system must be a studentphilologist, who is actively studying and researching Philology. Only in such a way we will develop future outstanding philologists and teachers. To understand modern way of Philology development, it is necessary to look at it from the historical-didactic point of view. There are different classifications of the history of Philology, mostly connected with its development on the territory of tsarist Russia, whose part Ukraine was (A. Hrolenko, K. Nagayeva, N. Doronina and others). We believe that history of Philology and Pedagogics is created by outstanding personalities. We have described 11 periods and shortly characterized the activities of outstanding philologists, historical figures, scientists and teachers. They are Pamvo Berynda, Yu. Rusin, I. Galyatovsky, S. Polynetsky, Friderich August Wolf, G. Scovoroda, V. Vernadsky, O. Potebnya M. Grushevsky, A. Makarenko, M. Grushevsky, L. Bulahovsky, P. Zhytetsky, M. Zhovtobryukh, M. Dvorzhetska, I. Korunets. The situation with COVID-19 has created the need in new content and methods of training philologists distantly. Professors have to equip themselves with the new content of work on new platforms and acquire new skills of teaching distantly. The research of the problem on the basis of competence-oriented paradigm of the organization of educational activities in higher school as the leading one and through the prizm of hierarchal formation of higher educational establishments student needs further studying and is a perspective vector of science development.

\section{References}

1. Рубінська Б. Про підходи до відбору компетенцій філолога. Міжнародний філологічний часопис. 2020. Вип. № 11 (3). C. 137-142. DOI: 10.31548/philolog2020.03.023.

2. Філолог. URL: https://kudapostupat.ua/profesia-filoloh. 
3. Жеребкина И. Введение в гендерные исследования : учебное пособие. Харьков, 2001. С. 51.

4. Малихін О., Рубінська Б. Про потенціал формування методологічної компетентності в галузі підготовки кваліфікованих спеціалістів в галузі філологічних спеціальностей. Педагогічні науки. Херсон, 2018. Вип. LXXXII. С. 176-181.

5. Греков Б. Киевская Русь. Москва, 1953. 567 с.

6. Левківський М. Історія педагогіки : навчально-методичний посібник. Київ, 2011. 190 с.

7. Хроленко А. История филологии : учебное пособие. Москва, 2013. $136 \mathrm{c}$.

8. Хижняк 3., Маньківський В. Історія Києво-Могилянської академіï. 2003. С. 74-76. URL: http://irbisnbuv.gov.ua/ulib/item/ UKR0000716 (дата звернення: 27.03.2021).

9. Нагаева К. История филологического знания. С. 6-7. URL: https://ru.calameo.com/read/005704444599fd494d854 (дата звернення: 27.03.2021).

10.Сковорода Григорій Савич. Вікіпедія : вільна енциклопедія. URL: https://uk.wikipedia.org〉wiki〉Сковорода_Григорій (дата звернення: 27.03.2021).

11.Дороніна Н. До історії розвитку іноземної філології в Київському університеті у XIX-XX ст. Етнічна історія народів Європи. Київ, 2011. Вип. 35. С. 86-89.

12.Потебня Александр Афанасьевич. Вікіпедія : вільна енциклопедія. URL: https://ru.wikipedia.org >wiki (дата звернення: 03.04.2021).

13. Латышина Д. История образования и педагогической мысли. Разд. I. URL: https://studentam.net/content/view/1536/125/ (дата звернення: 04.04.2021).

14.Шурхало Д. Михайло Грушевський після Центральної Ради: від боротьби за владу до «індивідуального подвигу». 2019. URL: https://www.radiosvoboda.org/a/29799890.html (дата звернення: 3.04.2021).

15.Грушевський Михайло Сергійович. Biкineдія : вільна енциклопедія. URL: https://uk. wikipedia.org>wiki>Грушевський_ Михайло (дата звернення: 03.04.2021).

16. Дороніна Н. До історії розвитку іноземної філології в Київському університеті у XIX-XX ст. Етнічна історія народів Європи. 2011. Вип. 35. С. 86-89. 
17. Латышина Д. История образования и педагогической мысли. Разд. I. URL: https://studentam.net/content/view/1536/125/ (дата звернення: 04.04.2021).

18.Ярмаченко М. Д. Макаренко Антон Семенович // Енциклопедія освіти / гол. ред. Василь Кремень. Київ, 2008. С. 471-472.

19.Видатні українські мовознавці. URL: myronivkaosvita.gov.ua/news.

20. Інститут філології Київського національного університету імені Тараса Шевченка. Вікіпедія : вільна енциклопедія. URL: https://uk.wikipedia.org/wiki/Інститут_філологіï_Київського_націона льного_університету_імені_Тараса_Шевченка (дата звернення: 04.04.2021).

21.Інститут філології Київського національного університету імені Тараса Шевченка. Вікіпедія : вільна енциклопедія. URL: https://uk.wikipedia.org/wiki/Інститут__іiлологіï_Київського _національного_університету_ імені__Тараса_Шевченка (дата звернення: 27.03.2021).

Information about the author: Rubinska B. I.,

Ph. D. in Pedagogy, Associate Professor, Associate Professor at the Department of Romance and Germanic Languages and Translation National University of Life and Environmental Sciences of Ukraine 19, Henerala Rodimtseva str., Kyiv, 03127, Ukraine 